\author{
"EU, A INDÚSTRIA E O MUNDO" \\ 08 a 11 de novembro de 2016 no campus Viçosa da UFV \\ Departamento de Engenharia de Produção e Mecânica - DEP \\ Universidade Federal de Viçosa - UFV
}

\title{
PREPARAÇÃO DE AMOSTRAS DO AÇO USI-CIVIL 350 DE PARA ANÁLISES METALOGRÁFICAS
}

\author{
Túlio Pinto Silveira \\ Universidade Federal de Viçosa-UFV, Departamento de Engenharia Mecânica e Produção \\ Campus UFV - 36570-000 - Viçosa - MG \\ tulio.silveira@ufv.br
}

\section{INTRODUÇÃ̃o}

As ligas metálicas são bastante utilizadas para diversas funções, desde ferramentas e máquinas industriais até na construção civil, com aplicações estruturais e o aço é a liga mais utilizada, por ser bastante versátil. Uma das formas de se classificá-los é através da quantidade de carbono presente: os de baixo carbono possuem no máximo $0,3 \%$, os de médio $0,3 \%$ a $0,6 \%$ e os de alto mais de $0,6 \%$. Essa quantidade de carbono altera a dureza do material, sendo essa crescente quando a quantidade de carbono também cresce (CBCA, 2014).

O aço USI-CIVIL 350 possui $0,23 \%$ em média de carbono e é bastante útil por ser ter alta resistência mecânica e ser de baixa liga, além de se enquadrar na categoria dos aços patináveis, os quais sob certas condições ambientais, podem desenvolver uma camada protetora contra a corrosão, formada por uma película de óxidos aderentes, a pátina. Com tais características ele é eficaz na construção de edifícios, pontes, navios e automóveis. Nesse trabalho, objetivou-se preparar amostras metalográficas desse aço, laminado à quente, para o estudo da relação entre o corte do material com a sua microestrutura.

\section{MATERIAIS E MÉTODOS}

Até a obtenção dos primeiros resultados, foi realizada uma série de procedimentos para preparação da peça, baseados em Rodhe (2010), que incluíram:

- Cortes da peça com cortadora metalográfica, sendo obtidas três amostras (uma através de um corte paralelo central, outra através de um corte transversal e a última representa a face superior);

- Embutimento das amostras: processo realizado em embutidora metalográfica manual e o material utilizado foi baquelite, o qual facilita os procedimentos seguintes;

- Lixamento e polimento das peças: realizados em uma lixadeira manual e uma politriz para que as peças ficassem planas e pudessem ser bem analisadas;

- Ataque químico: reagiu-se as peças com Nital 2\% (que tem como objetivo melhor visualização dos contornos de grão), e assim, pode-se realizar a última etapa da preparação;

- Captura de imagens no microscópio.

\section{RESULTADOS}

Como resultados deste trabalho obteve-se três amostras de planos diferentes de uma peça de aço USI-CIVIL 350 e imagens das mesmas com e sem ataque químico em lentes de aumento de 5 até 100 vezes são apresentadas nas Fig. 1, 2 e 3. 


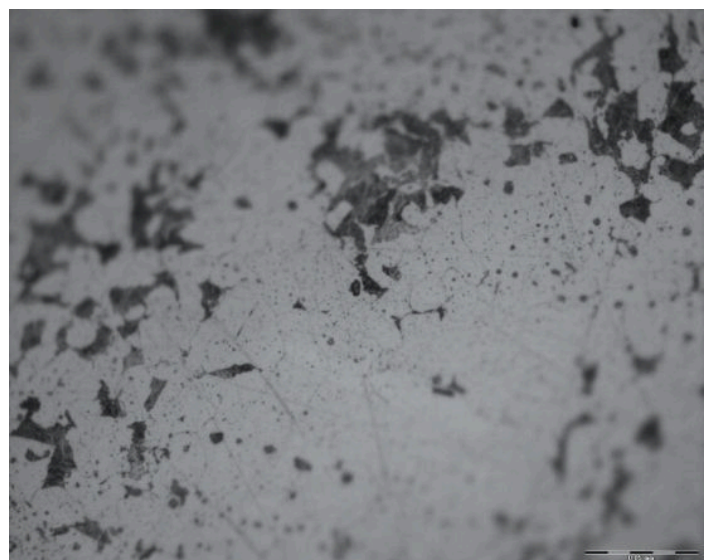

Figura 1 - amostra 2 com ataque de 15 s e aumento $50 x$.

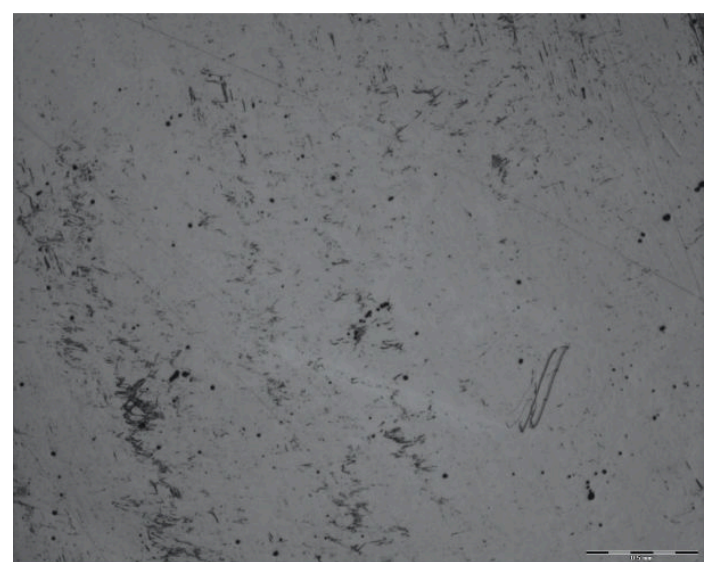

Figura 2 - Amostra 1 com ataque de 10s e aumento de 5x.

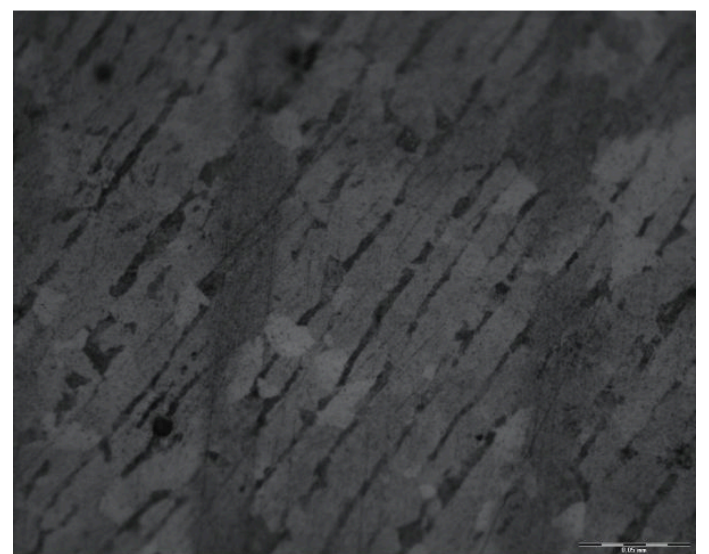

Figura 3 - Amostra 3 com ataque de 15 s e aumento de 50x.

Tais amostras encontravam-se prontas para análises metalográficas que tem por objetivo comparar possíveis diferenças microestruturais entre os planos oriundas dos cortes na peça. Estas análises serão abordadas em trabalhos futuros.

\section{CONSIDERAÇÕES FINAIS}

Foi detectado pelo aluno como passíveis de melhora em futuros trabalhos a realização das etapas de lixamento, pois ao microscópio observou-se presença de riscos e obtenção das imagens, em algumas fotos a região da microestrutura focada não permitia perfeita visualização do contorno dos grãos. 


\section{AGRADECIMENTOS}

À CAPES, pelo incentivo e introdução de alunos ao meio de pesquisas científicas ainda no primeiro ano acadêmico, com a realização do Programa Jovens Talentos para a Ciência, ao Professor e Orientador Charles Luís da Silva, ao Professor Alexandre Martins Reis, aos Funcionários e Técnicos do DEP - Departamento de Engenharia de Produção e Mecânica da UFV, pelo acompanhamento durante todo o projeto e ao Tarcísio Mauro Batista Filho, colega de projeto.

\section{REFERÊNCIAS}

ASSOCIAÇÃO BRASILEIRA DE NORMAS TÉCNICAS. "NBR 6023: Informação $e$ documentação”, Rio de Janeiro, 2002. 24 p.

ROHDE, R. A. "Metalografia preparação de amostras: uma abordagem prática”, 2010. Disponível em: <http://www.urisan.tche.br/ lemm/metalografia.pdf $>$ Acesso em: 15 ago. 2014.

CBCA, "Construção em aço/Aços estruturais". 2014. Disponível em: <http://www.cbcaacobrasil.org.br/site/construcao-em-aco-acos-estruturais.php $>$. 